\title{
New Record of Chara Hispida (L.) Hartm. (Streptophyta: Charophyceae, Charales) from the Işıklı Lake (Turkey) and Critical Checklist of Turkish Charophytes
}

\author{
Sophia Barinova ${ }^{1, *}$, Roman Romanov ${ }^{2}$, Cuneyt Nadir Solak ${ }^{3,4}$ \\ ${ }^{1}$ Institute of Evolution, University of Haifa, Mount Carmel, Haifa 31905, Israel \\ ${ }^{2}$ Central Siberian Botanical Garden, Siberian Branch of the Russian Academy of Sciences, 630090, Novosibirsk, Russia \\ ${ }^{3}$ Department of Biology, Dumlupinar University, 43100, Kutahya, Turkey \\ ${ }^{4}$ Department of Palaeoceanology, Institute of Marine Sciences, University of Szczecin, Mickiewicza 18, 70-383, Szczecin, Poland \\ *Corresponding Author: barinova@research.haifa.ac.il
}

Copyright (C) 2014 Horizon Research Publishing All rights reserved.

\begin{abstract}
Chara hispida (L.) Hartm. has been found in the Işıklı Lake (Western Anatolia). The specimens are described; distribution and ecology of C. hispida are discussed. The bio-indication shows that the Işsklı Lake is mainly an oligotrophic state with a trend to a mesotrophic state, and fresh low-alkaline water with low to middle organic pollution. A check-list of charophytes was compiled. There are sixteen species of charophytes known from Turkey, including 13 species of Chara and 3 species of Nitella.
\end{abstract}

Keywords Chara hispida, ecology, distribution, Işıklı Lake, Turkey

\section{Introduction}

Chara hispida (L.) Hartm. is widespread and relatively common in Europe. The species concepts of $C$. hispida in different regions are not identical. This mainly European species was found in the European and Asian parts of Turkey ([1-5]; this study). The Turkish localities are marginal in terms of distribution range and the frequency of occurrence. Therefore, the morphology and ecology of C. hispida from these border habitats deserve special attention to reveal the ranges of morphological and ecological variability and to create verifiable and reliable records of the species.

The charophyte flora of Turkey is poorly described and documented despite the comparatively large bibliography (see below). As in other regions of the Near East, the accurate and detailed documentation of species' findings in Turkey is really needed to avoid confusions and ambiguities of several species records. The lack of information is accentuated by the absence of voucher specimens or published records of its existence. To date, descriptions and illustrations of $C$. hispida specimens from the Near East exclaves are absent. In Turkey $C$. hispida had been collected from drainage channels and lakes ([1-3]; this study). The exact localities of species usually were not mentioned in published data, but at least three were known from Western and Southern Anatolia and Marmara regions, respectively, in drainage channels of Kaş Ova Gelemiş in Muğla Province [4], in Salda Lake in Burdur Province [1,3] and in the vicinity of Istanbul [5]. Detailed descriptions of this species were missing, as well as its ecology and habitats. Attention was given only to a few biological activities of this species $[1,3,6]$.

Freshwater algae are widely used as bio-indicators of aquatic environment [7], but this system is just in initial step in Turkey $[8,9]$. Recently, a bio-indication approach in the Eastern Mediterranean has been developed in Israel [10]. We implemented a summarized account on species autecology $[11,12]$ for the algal community from the Işıklı Lake to characterize the environment in which $C$. hispida was found.

The aim of the present study is to describe a new record of C. hispida's locality for Turkey, to characterize C. hispida's environment using bioindication methods, and to compile an annotated species check-list of Turkish charophytes.

\section{Materials and Methods}

\subsection{Description of the Study Site}

Lake Işıklı $\left(38^{\circ} 14^{\prime} \mathrm{N} ; 2^{\circ} 55^{\prime} \mathrm{E}\right)$ is located in the basin of the Büyük Menderes River in the western part of Turkey (Figures 1,2). It is an alluvium embankment in a freshwater lake formed by the Kufi stream close the riverbed of the Büyük Menderes River, which is home to numerous historic sites [13].

The river flows across the lake to the Aegean Sea and is a part of Western Anatolia in the Freshwater Ecoregions of the World (FEOW) [14]. The climate of this region is mild, having a transitional state between Mediterranean and cool, 
temperate climates. The annual average air temperature is $15.8^{\circ} \mathrm{C}$ (min. -11.6 ; $\max .41 .2{ }^{\circ} \mathrm{C}$ ) [15]. Altitude of the Lake Issılk is $850 \mathrm{~m}$. The lake has a surface area that varies from 35 to $66.5 \mathrm{~km}^{2}$ with a maximum of $73 \mathrm{~km}^{2}$; the maximum depth of the lake is $7.0 \mathrm{~m}$ and the mean depth is $3.77 \mathrm{~m}$. The average depth of Lake Işıklı seasonally fluctuated between 1.60 and $3.15 \mathrm{~m}$ [16]. Lake water transparency and biomass of macrophytes also fluctuated between dry and wet seasons. As a result of the lake level's seasonal fluctuation, coastal areas are exempt from the lake water during the dry season, and the lake's shore is covered with a mass of dried plants and Chara. The most common macrophytes in the lake area were identified as Chara spp., Ceratophyllum demersum, Potamogeton lucens, Myriophyllum spicatum, Polygonum amphibium, and Potamogeton pectinatus. The lake water is used for the purpose of irrigation and wildlife [15].

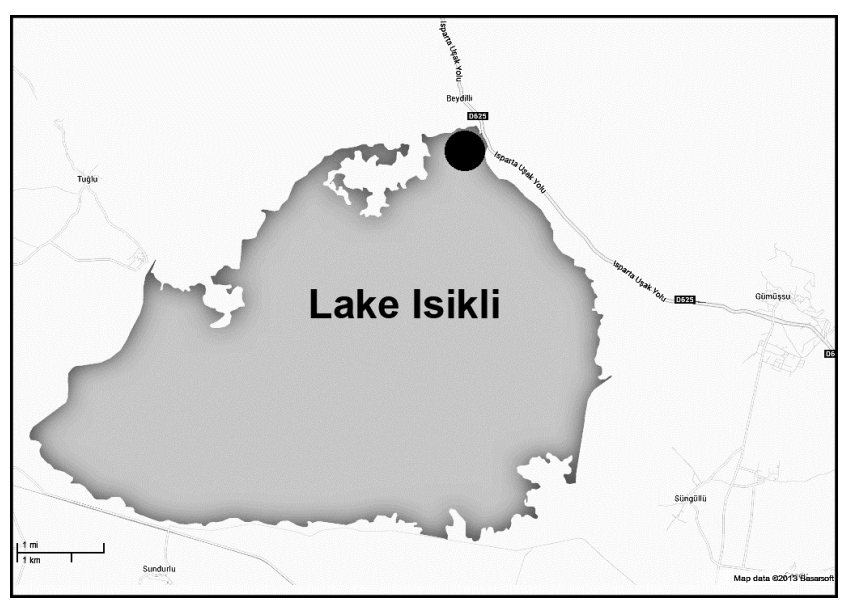

Figure 1. Map of study site with sampling point as black circle
Chemical data for species ecology come from $[16,17]$.

\subsection{Sampling and Cleaning}

Charophyte samples were taken by Dr. Erdoğan in the northeast part of the lake by scooping, fixed in formaldehyde 4\% solution, and transported to the Dumlupinar University in an ice box. Part of the samples were sent to the Institute of Evolution, University of Haifa and studied under a Nikon light microscope and Leica stereomicroscope with digital cameras under magnification Ч 100-1000. Part of charophyte samples was sent to the Central Siberian Botanical Garden and studied under a stereomicroscope Carl Zeiss Stereo Discovery V12 and micrographs were taken with the digital camera AxioCam MRS-S and Axiovision 4.8 software.

The diatom samples were collected by Dr. Erdoğan by using plankton net $(25 \mu \mathrm{m}$ mesh) from $0-70 \mathrm{~cm}$ depth of the lake. Periphyton from charophytes and planktonic samples were boiled in $\mathrm{H}_{2} \mathrm{O}_{2}$ and $\mathrm{HCl}$ to remove calcium carbonate and organic matter. After washing several times with distilled water, the material was air-dried on cover glasses and mounted in Naphrax ${ }^{\circledR}$. The diatoms were observed with a Nikon Eclipse $\mathrm{Ci}$ and light Microscopes (LM) in Dumlupınar University Research Center (ILTEM).

\section{Results}

\subsection{Description of the Chara Hispida Specimens}

Taxonomy and nomenclature of Chara hispida (L.) Hartman 1820 is given according to [18].

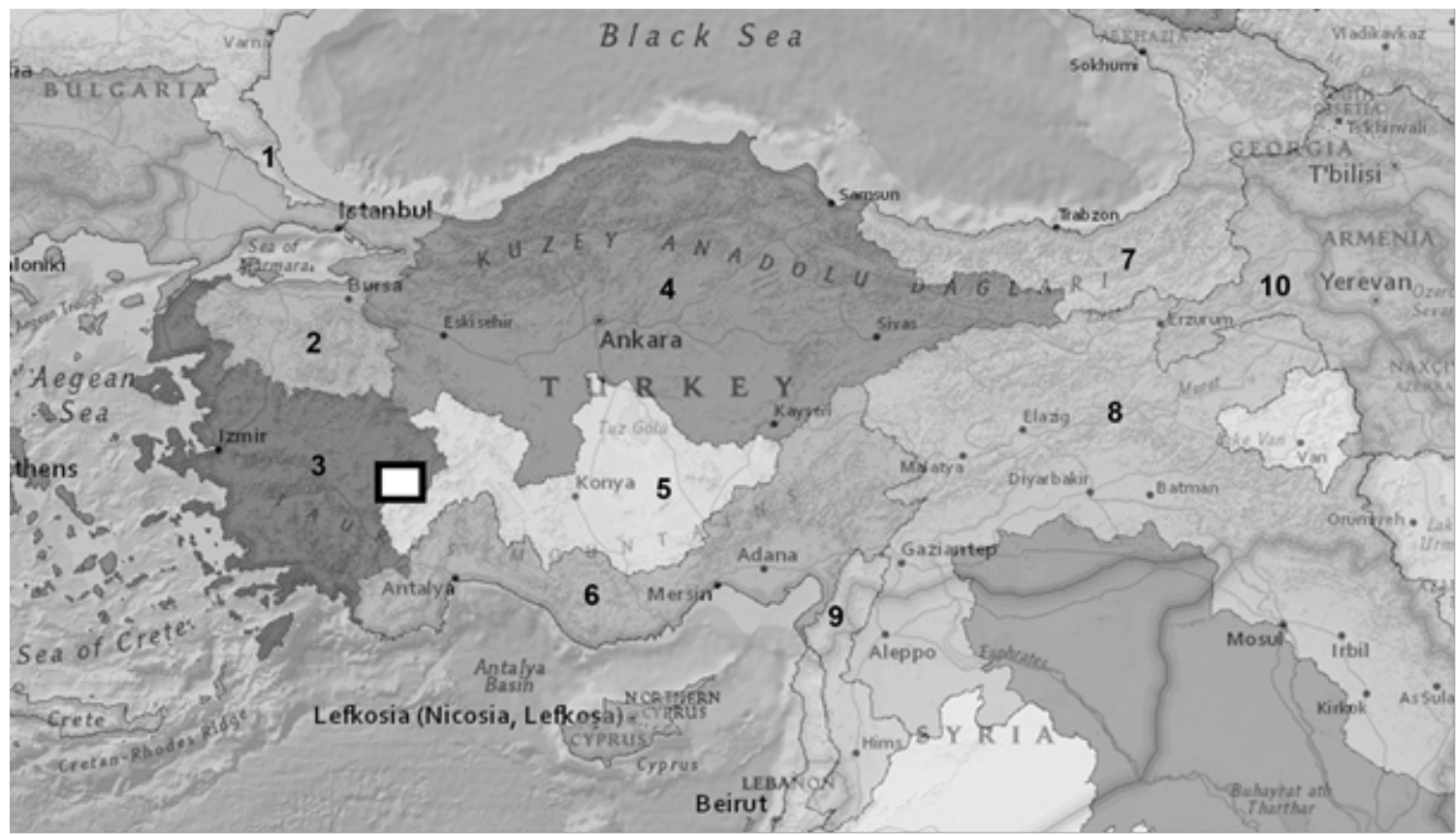

Figure 2. The Işıklı Lake study site, Turkey, on the map of Freshwater Ecoregions of the World (according to [14]. (1 - Dniester-Lower Danube, 2 Thrace, 3 - Western Anatolia, 4 - Northern Anatolia, 5 - Central Anatolia, 6 - Southern Anatolia, 7 - Western Trascaucasia, 8 - Upper Tigris \& Euphrates, 9 - Orontes, 10 - Kura-Southern Caspian). 


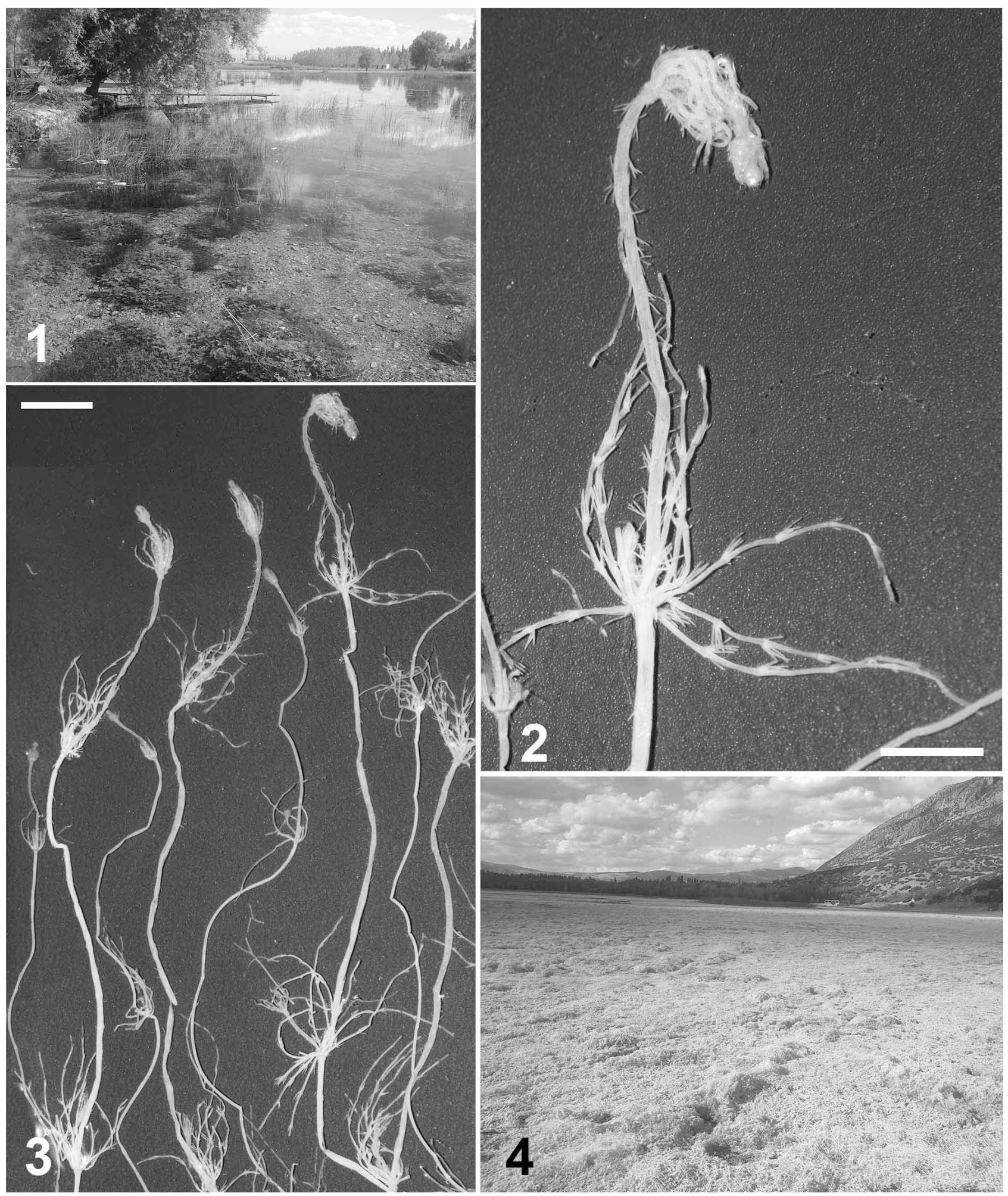

Figure 3. Chara hispida habitat and plant overview. 1 - stands, 2,3-upper parts of plants, 4 -dry beds with Chara hispida as a result of water level decline. Scale bar $2 \mathrm{~cm}$ 

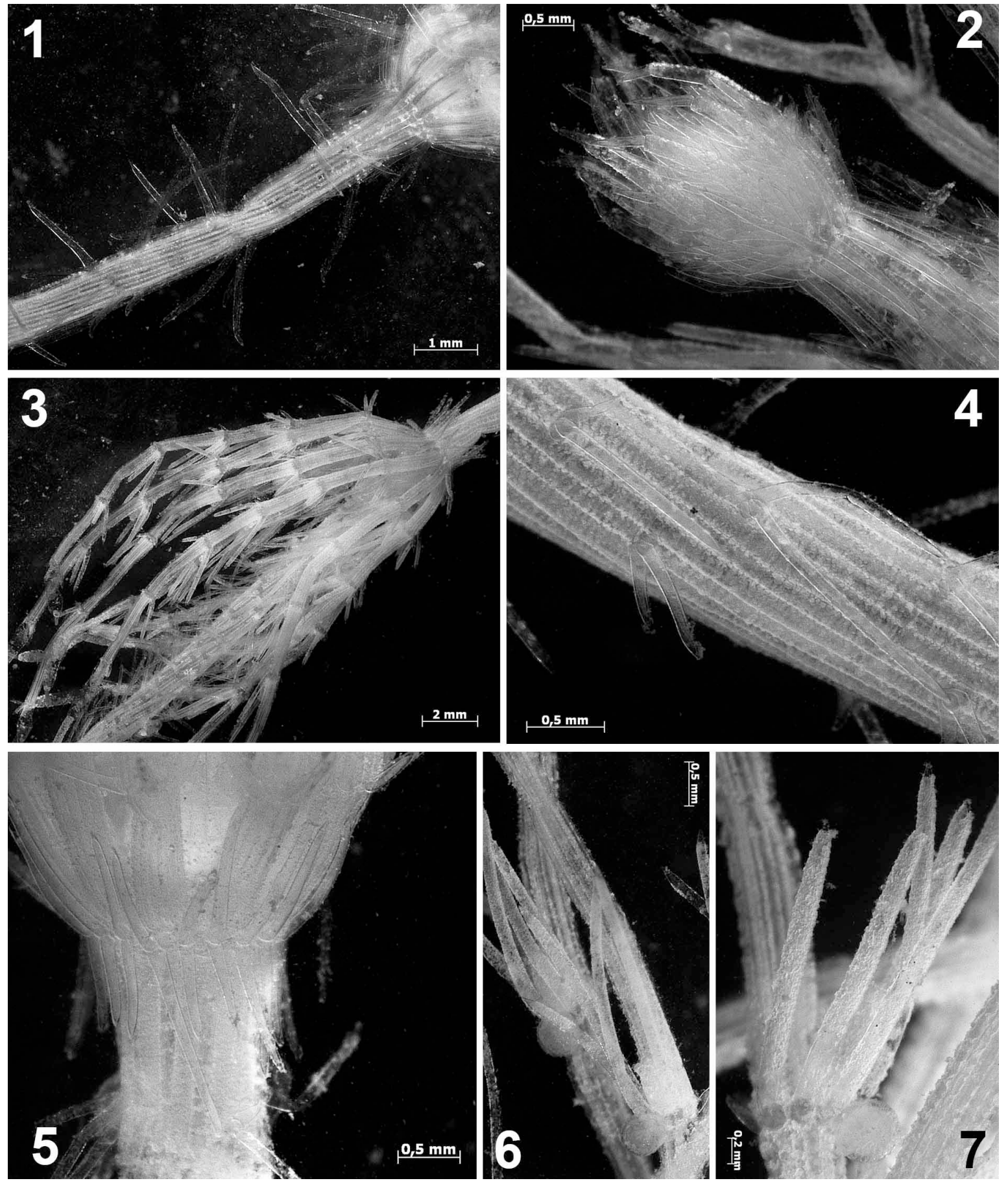

Figure 4. Chara hispida morphology: 1 - axis and base of whorl, 2 - apex, 3 - whorl of branchlets, 4 - axial cortex, 5- stipulodes, 6, 7-gamentangia

Synonyms: Chara major Vaillant 1719; Chara hispida var. maior (L.) Hartman f. maior in R.D.Wood 1962, Chara hispida var. maior (L.) Hartman f. maior in R.D.Wood et Imahori 1965.

The plants are moderately incrusted, above $35 \mathrm{~cm}$ in height (only upper parts were available for study), scarcely branched (Figures 3,4), with robust axes $0.7-1.5 \mathrm{~mm}$ in diameter. Axes cortex diplostichous obviously or slightly aulacanthous, on older internodes usually isostichous; spine-cells are acute usually in clusters of 3 , one or rarely two of them very short papillose, others are from 0.25 to 3 times longer of axis diameter, dense on younger internodes and solitary short conical on older internodes. The stipulodes are in 2 tiers, 2 sets per branchlet, well developed, acute, similar in shape with cortex spine-cells. The branchlets are $2.7-5.6 \mathrm{~cm}$ in length, in 9-10 in a whorl, in 1.6-2-3-(4) times shorter of internodes, consist of 5-7 corticate segments and moderately long two-celled ecorticate end segment, and end cell is acute. The bract cells are verticillate, the anteriors elongate, and posteriors significantly shorter. The gametangia are solitary, conjoined, unripe, antheridia up to $460 \mathrm{mkm}$ in diameter. 
Table 1. Diversity of algae in the charophyte community of the Isikli Lake in September 2013 with abundance scores and species autecology

\begin{tabular}{|c|c|c|c|c|c|c|c|c|c|c|c|c|}
\hline & Taxa & Scor & Sub & $\mathrm{T}$ & Oxy & Hal & $\mathrm{pH}$ & $\mathrm{D}$ & Sap & $\mathrm{s}$ & Aut-Het & Tro \\
\hline 1 & Chara hispida (L.) Hartman & 6 & B & - & st & $\mathrm{i}$ & - & - & $\mathrm{x}-\mathrm{b}$ & 0.9 & - & - \\
\hline 2 & Brachysira vitrea (Grunow) Ross in Hartley & 1 & B & - & - & $\mathrm{i}$ & ind & - & $0-x$ & 0.7 & - & - \\
\hline 3 & Cocconeis placentula Ehrenberg var. placentula & 1 & P-B & temp & st-str & $\mathrm{i}$ & alf & es & o-b & 1.4 & ate & $\mathrm{e}$ \\
\hline 4 & Cocconeis placentula var. euglypta (Ehrenberg) Grunow & 1 & P-B & temp & st-str & $\mathrm{i}$ & alf & sx & $\mathrm{b}$ & - & ate & e \\
\hline 5 & Cocconeis placentula var. lineata (Ehrenberg) van Heurck & 1 & P-B & - & st-str & $\mathrm{i}$ & alf & sx & $\mathrm{x}-\mathrm{O}$ & 0.4 & ate & $\mathrm{e}$ \\
\hline 6 & Cymbella cymbiformis Agardh & 1 & B & temp & str & $\mathrm{i}$ & neu & sx & o & - & ats & $\mathrm{o}-\mathrm{m}$ \\
\hline 7 & Cymbella hustedtii Krasske & 1 & B & - & str & $\mathrm{i}$ & alf & - & o & - & ats & o-m \\
\hline 8 & Cymbella lange-bertalotii Krammer & 2 & B & - & st-str & $\mathrm{i}$ & alf & sx & o-b & 1.5 & ats & $\mathrm{e}$ \\
\hline 9 & Cymbella vulgata Krammer & 1 & - & - & - & - & - & - & - & - & - & - \\
\hline 10 & Denticula kützingii Grunow & 2 & B & - & str & $\mathrm{i}$ & alb & - & $o-b$ & 1.5 & ats & $\mathrm{m}$ \\
\hline 11 & Encyonema caespitosum Kützing & 1 & B & - & - & - & - & sx & $\mathrm{b}-\mathrm{a}$ & - & - & - \\
\hline 12 & Encyonopis eifelana Krammer & 1 & - & - & - & - & - & - & - & - & - & - \\
\hline 13 & Encyonopsis microcephala (Grunow) Krammer & 2 & B & - & str & $\mathrm{i}$ & alf & es & $\mathrm{b}$ & - & ats & me \\
\hline 14 & Encyonopsis minuta Krammer et Reichardt & 6 & B & - & - & oh & - & - & - & - & - & - \\
\hline 15 & Encyonopsis moseri Krammer et Lange-Bertalot & 1 & - & - & - & - & - & - & - & - & - & - \\
\hline 16 & Encyonopsis sp. & 1 & - & - & - & - & - & - & - & - & - & - \\
\hline 17 & Encyonopsis subminuta Krammer et Reichardt & 1 & B & - & st-str & $\mathrm{i}$ & ind & sx & $\mathrm{x}-\mathrm{O}$ & 1.3 & ate & o-e \\
\hline 18 & Epithemia adnata (Kützing) Brébisson & 1 & B & temp & st & $\mathrm{i}$ & alb & sx & $\mathrm{b}-\mathrm{a}$ & 2.5 & ats & me \\
\hline 19 & Epithemia smithii Carruthers & 6 & B & - & - & - & - & sx & - & - & - & - \\
\hline 20 & Eunotia arcus Ehrenberg & 2 & $\mathrm{~B}$ & - & - & $\mathrm{i}$ & acf & - & $\mathrm{x}-\mathrm{b}$ & 0.8 & ats & o-m \\
\hline 21 & Gomphonema sp. & 1 & - & - & - & - & - & - & - & - & - & - \\
\hline 22 & Mastogloia dansei (Thwaites) Thwaites ex W.Smith & 1 & B & - & - & $\mathrm{mh}$ & alf & - & - & - & - & - \\
\hline 23 & Mastogloia elliptica (Agardh) Cleve & 4 & B & - & - & $\mathrm{mh}$ & alf & - & - & - & - & - \\
\hline 24 & Mastogloia lacustris (Grunow) Grunow & 1 & B & - & str & hl & alf & - & o & 1 & ats & $\mathrm{e}$ \\
\hline 25 & Navicula cryptotenelloides Lange-Bertalot & 1 & B & - & - & oh & alf & - & $\mathrm{b}-\mathrm{a}$ & - & - & - \\
\hline
\end{tabular}

Note: Substrate (Sub) - substrate preferences (P-B - plankto-benthic, B - benthic); Temperature (T) - temperature preferences (temp - temperate); Oxygenation (Oxy) - streaming and oxygenation (st - standing water, str - streaming water, st-str - low streaming water); Salinity (Hal) - halobity degree according to [42] (i - oligohalobes-indifferent, $\mathrm{mh}$ - mesohalobes, $\mathrm{hl}$ - halophiles; oh - undifferent oligihalobes); Acidity ( $\mathrm{pH}$ ) - $\mathrm{pH}$ degree according to [43] (alb-alkalibiontes; alf - alkaliphiles, ind - indifferents; acf - acidophiles; neu - neutrophiles as a part of indifferents); Saprobity DAIpo (D) - degree of saprobity according to [44] (sx - saproxenes, es - eurysaprobes); Autotrophy-Heterotrophy (Het) - nitrogen uptake metabolism [11] (ats nitrogen-autotrophic taxa, tolerating very small concentrations of organically bound nitrogen; ate - nitrogen-autotrophic taxa, tolerating elevated concentrations of organically bound nitrogen); Trophy (Tro) - trophic state [11] (o-m - oligo-mesotraphentic; $\mathrm{m}$ - mesotraphentic; me - meso-eutraphentic; e - eutraphentic; o-e - oligo- to eutraphentic (hypereutraphentic)); Saprobity S (Sap) - degree of saprobity [45] (x-o - xeno-oligosaprobes, o-x oligo-xenosaprobes, $\mathrm{x}$ - $\mathrm{b}$ - xeno-betamesosaprobes, $\mathrm{o}$ - oligosaprobes, $\mathrm{o}-\mathrm{b}$ - oligo-betamesosaprobes, $\mathrm{b}$ - betamesosaprobes, $\mathrm{b}$ - $\mathrm{a}$ - beta-alphamesosaprobes); $\mathrm{s}-$ species-specific saprobity index [12].

\subsection{Habitat Description}

The Işıklı Lake, on depth 0-70 $\mathrm{cm}$, with average values of $15.35 \mathrm{~kg} \cdot \mathrm{m}^{-2}$ (wet) and $2.0 \mathrm{~kg} \cdot \mathrm{m}^{-2}$ (dry) in environmental condition as: $\mathrm{pH} 8.42-7.85$, Conductivity $329-448 \mu \mathrm{Sm} / \mathrm{cm}$, Temperature $5.6-28.1^{\circ} \mathrm{C}$ with average $15.6{ }^{\circ} \mathrm{C}$, Dissolved Oxygen 6.57-10.96 mg L${ }^{-1}$, Chloride 19.65-13.48 $\mathrm{mg} \mathrm{L}^{-1}$, Organic matter 26.70-19.93 $\mathrm{mg} \mathrm{L}^{-1}$, NTU 2.53-8.07, Bicarbonate $158.60-252.26 \mathrm{mg} \mathrm{L}^{-1}$, Carbonate 3.16-17.85 mg L ${ }^{-1}$, Hardness 21.01-30.76 ${ }^{\circ} \mathrm{F}$, Calcium 43-08-82.79 mg $\mathrm{L}^{-1}$, Magnesium 25.92-29.78 $\mathrm{mg} \mathrm{L}^{-1}$, Nitrate $0.91-1.01 \mathrm{mg}$ $\mathrm{L}^{-1}$, Sulfate $36.94-67.13 \mathrm{mg} \mathrm{L}^{-1}$, Phosphate $0.06-0.08 \mathrm{mg} \mathrm{L}^{-1}$, Ammonia $0.41-1.18 \mathrm{mg} \mathrm{L}^{-1}$, Hydroxyl $0.00 \mathrm{mg} \mathrm{L}^{-1}$, Salinity $0.00 \%$, Carbon dioxide $0.53-1.08 \mathrm{mg} \mathrm{L}^{-1}$, together with aquatic plants Ceratophyllum demersum, Potamogeton lucens, Myriophyllum spicatum, Polygonum amphibium, and
Potamogeton pectinatus [16]. The habit of studied specimens likely reflects comparatively low-light intensity in C. hispida's habitat [19].

\subsection{Distribution of C. Hispida}

Species is widespread and relatively common in Europe, in Northern Europe its distribution connected to limestone areas [20]. Chara hispida had been found in nearly all states in Europe, i.e. in Serbia, Croatia, Macedonia, Slovenia, Bosnia and Herzegovina, Bulgaria, Greece [21], Romania [22], Czech Republic [23], Slovakia [24], Austria [25], Latvia [26], Lithuania [27], Belgium [28], Netherlands (as $C$. major (Hartm.) Hy [29], Switzerland [30], Germany [31], Poland [32], Russia [33], Kazakhstan [34], Denmark, Norway, Sweden [20], Portugal, Spain, France, Hungary, 
Italy, Ukraine [35], Great Britain, Ireland [36]. In Asia $C$. hispida had been reported from Egypt [37], Oman [38], Jordan [37], Turkey [5,35], Azerbaijan [33], Kazakhstan [39] and Russia [5]. In Africa it is known from Atlas Mountains in Morocco [40] Algeria and Tunis [41]. So it may be concluded that $C$. hispida have mainly European areal with few exclaves in Northern Africa, Near East, Caucasus, Central Asia and Eastern Siberia, but revision of several records outside of main part of its areal is needed.

\subsection{Bio-indication of the $C$. Hispida Environment}

We use bio-indication methods on the basis of algal and invertebrate species, which inhabit lake water and substrates, for the purpose of characterizing the water quality of the lake in which C. hispida grows.

Altogether, twenty-five algal species were occupied the $C$. hispida plants. We found diatom species only (Table 1). Most abundant in the periphytic community were Encyonopsis minuta Krammer et Reichardt, and Epithemia smithii Carruthers. Periphytonic algae characterize the environment in which C. hispida inhabits, such as temperate, low alkaline, middle oxygenated fresh waters with low to middle organic pollution. As can be seen in Table 1, algal species survived mostly as benthic forms, but plankto-benthic life forms was also presented. Species-specific index of saprobity fluctuated from 0.7 to 2.5 . We calculated the Index of saprobity $\mathrm{S}$ for the algal community according to [46] and found it as 1.13, which reflects Water Quality Class II. In this way, we analyzed species nutrition preferences (Table 1), and found algal species used only photosynthesis for biomass production; however, mixotrophic species were absent. Bio-indication can help us to assess a trophic state of the lake (Table 1) and shows that Işıklı is an oligotrophic lake. Lacoul \& Freedman [47] characterized C. hispida as an oligotraphent species, which have species optimum in an oligotrophic lake environment.

Therefore, bio-indication shows that Işıklı Lake mainly has an oligotrophic state with a trend to the mesotrophic state, and fresh low-alkaline water with low-to-middle organic pollution.

\section{Discussion}

\subsection{Ecology and Habitats}

Chara hispida is one of the largest species of charophytes; usually its thallus height is between 0.3-2 $\mathrm{m}$ [35], and occasionally individual plants may be $3.5 \mathrm{~m}$ in length [48]. It often forms dense perennial beds [36] with depths up to $15 \mathrm{~m}$, mainly between $0.5-2 \mathrm{~m} \mathrm{[35]} \mathrm{or} \mathrm{2-7} \mathrm{m} \mathrm{[49];} \mathrm{annual} \mathrm{forms} \mathrm{are}$ known from shallow water $[20,50]$; sometimes its pure stands are formed in groundwater output [35]. Chara hispida beds may form a significant part of clear-water calcareous lake vegetation; this is one of the key species in "Hard oligo-mesotrophic waters with benthic vegetation of Chara spp." according to the European Union Habitat Directive (NATURA 2000 Code: 3140). Its abundance and vitality may be used as an indicator of favorable conditions in these ecosystems [51]. Chara hispida beds could be acting as nitrogen sinks in several lakes [52]. Its stands create a specific habitat for plankton, particularly via space structuring and refuge forming for zooplankton [53] and in the formation of allelochemicals, probably impacting phytoplankton [54].

Chara hispida is eurythermal, alkalifilic [49], oligotraphentic [47,55], and indifferent to light intensity species $[49,56]$; it prefers calcareous-oligosaprobic waters [35].

This species grow in freshwater calcareous alkaline pools and lakes $[20,36]$ as well as in small water bodies [50], peat bogs and water holes in calcareous fens [35], including habitats, which dry out for short periods [36]. Occasionally, C. hispida occurs in brackish waters [50,57] therefore, it may be characterized as indifferent to salinity [50]. It may be concluded that Chara hispida may grow in a comparatively wide range of water-body types. It frequently shares the same habitats with other species of Chara and Nitellopsis obtusa (Desv. in Loisel.) J. Groves. Moreover, it seems extremely problematic to achieve clear habitat specificity differentiation from other species of Chara as well as to attempt to explain the extant distribution of C. hispida through preferred habitat types.

Chara hispida as another large species of charophytes that can't successfully persist in shallow waters, which is likely due to the high susceptibility to mechanical damage by waves and ice cover; its distribution is restricted to deeper water [58]. Therefore, it may completely disappear from a water body after water transparency decreases as a result of eutrophication [58] and sometimes can't reappear and regenerate its own community after restoring previous low-trophic levels of the water ecosystem [59]. Its successful recolonization of clear-water lakes, shifting from turbid plankton-dominated state, is known from the Netherlands [60] and Sweden (Blindow, cit. [51]).

\subsection{Check-list of Turkish Charophytes}

We shared published information about charophyte species distribution in the territory of Turkey for the purpose of finding localities of the studied species C. hispida in the list of Turkish Charales. Unfortunately, less than half of the charophyte species reported from Turkey was included in the last check-list of algae [62]. Therefore, we compiled a preliminary check-list of charophytes for Turkey, excluding records of Chara sp. and Nitella sp. The 13 species of Chara and 3 species of Nitella had been reported from Turkey, which is similar to Israel species richness with 15 charophyte 
species and one variety $[63,64]^{1}$, Iran [65-69] with 19 species and two varieties, and Georgia with 14 species [70], and contrary to dry climatic habitats in Arabian Peninsula with 11 species and two varieties in Saudi Arabia [71-73], and eight charophyte species and one variety in Oman $[67,74]$.

Below we presented an annotated check-list with the references included in our findings of $C$. hispida. The revision of several records is needed.

1. Chara aspera Willd. (as C. globularis Thuill. var. aspera R.D. Wood, [2,4].

2. C. canescens Desv. et Loisel. in Loisel. $[62,75,76]$.

3. C. globularis Thuill $[2,4,62,76]$, as $C$. fragilis $\mathrm{f}$. hedwigii (C.Ag. in Bruz.) Kütz., [5]; as C. fragilis Desv. [77].

4. C. gymnophylla A.Br. [78], as C. foetida subsp. gymnophylla $\beta$ fontanesiana $\mathrm{A}$. Br., [5]; as $C$. vulgaris var. gymnophylla (A.Br.) Nym. [62].

5. C. hispida L. [1-6,35,50,78,79], this study.

6. C. inconnexa T.F. Allen (as $C$. vulgaris var. inconnexa (T.F. Allen) R.D. Wood, $[2,4,62]$.

7. C. intermedia A.Br. $[5,36,78]$.

8. C. kieneri Daily (as C. vulgaris f. kieneri (Daily) Norton ex R.D. Wood, [62].

9. C. tenuispina A.Br. [35].

10. C. tomentosa L. $[2,4,35,79]$, as C. ceratophylla Wallr. $[5,78]$.

11. C. virgata Kütz. (as C. globularis var. virgata (Kütz.) R.D. Wood, $[2,4]$.

12. C. vulgaris L. $[2,4,62,76,80-83]$, as C. foetida A.Br., [5]; as C. foetida (subhispida) [77].

13. C. zeylanica Klein ex Willd. $[2,5]$.

14. Nitella gracilis $(\mathrm{Sm}$.) C. Agardh [2]; also $N$. cf. gracilis had been reported [5].

15. N. mucronata (A.Br.) Miq. in H.C. Hall $[35,78,84]$, as N. mucronata var. virgata (Wallm.) A.Br. [5].

16. N. opaca C. Agardh [81,85], as N. opaca f. heteromorpha Mig. [80].

\section{Conclusion}

Charophyte species $C$. hispida's beds represent one of the less studied habitats in the Işıklı Lake. A detailed study of morphology, ecology, and distribution of C. hispida confirm species ecology as inhabiting oligotrophic freshwater, low-alkaline lakes with low-to-middle organic pollution. This species can form a large biomass as a result of growth in a stable environment. Periodically exposing the lake bedrocks as a result of the lake level's seasonal fluctuation is obviously the cause of dead C. hispida thalli. But the life cycle of Chara with oospores' formation helps in renewing the algal growth during the wet season with restoration of the large biomass, likely with average values $15.35 \mathrm{~kg} \mathrm{~m}^{-2}$ (wet)

\footnotetext{
${ }^{1}$ A comprehensive bibliography for Israel, Iran, Georgia and Saudi Arabia charophytes is impossible to report within the scope of this article, so here and below are the cited references of those that include all known species from the territory.
}

and $2.0 \mathrm{~kg} \mathrm{~m}^{-2}$ (dry) [as Chara spp., 15]. Therefore, we can conclude that the studied lake has optimal environment for growing of $C$. hispida in Turkey. In this case we recommended the Işıklı Lake to be included in the Turkish net of protected areas with regular monitoring of chemical and biological variables, and watershed protection.

\section{Acknowledgements}

We give thanks to Dr Omer Erdoğan from the Süleyman Demirel University, Isparta, Turkey, for his help on collecting samples in the lake. This work has been partly funded by Israel Ministry of Absorption.

\section{REFERENCES}

[1] Atıc1, T., I. Orhan, P. Wisespongpand \& B. Şener. Evaluation of some biological activities of Chara hispida L., J. Fish. Aquat. Sci., Vol.18, No.1: 167-171, 2001.

[2] Anonymous. Su yabanc otları. Yayılış alanları, yaşamları, çevresel ilişkileri, sorunları ve Savaşım Yöntemleri. Ankara: DSİ İdari ve Mali İşler Dairesi Başkanlığı, Basım ve Foto-Film Şube Müdürlüğü, Website: http:/www.dsi.gov.tr/docs/yayinlarimiz/su-yabanci-otlari.pd f?sfvrsn=4 [accessed 27 October 2013], 2009.

[3] Kartal, M., I. Orhan, M. Abu-Asaker, F.S. Şenol, T. Atıcı \& B. Şener. Antioxidant and anticholinesterase assets and liquid chromatography-mass spectrometry preface of various freshwater and marine macroalgae, Pharmacognosy Magasine, Vol.5, No.20: 291-297, 2009.

[4] Altınayar, G. \& N.F. Onursal. Sulama sistemlerin sorun yaratan su yabancı otlarının türleri ve yayılış alanları üzerinde çalışmalar, Bitki koruma bülteni, Vol.22, No.3: 120-141, 1982.

[5] Braun, A. \& O. Nordstedt. Fragmente einer Monographie der Characeen. Nach den hinterlassenen Manuskripten A. Braun's herausgegeben von Dr. Otto Nordstedt, Abhandlungen der kцniglichen Akademie der Wissenschaften zu Berlin 1882, Berlin, 1882.

[6] Orhan, I., M. Kartal, M. Abou-Asaker, F.S. Şenol, T. Atıcı \& B. Şener. Antioxidant appraisal and LC_MS characterization of some freshwater and marine macrophytes and algae, Planta Med., Vol.74, No.9: PC75, 2008.

[7] Bellinger, E.G. \& D.C. Sigee. Fresh water algae (Identification and use as bioindicators). John Wiley and Sons, Chippenham, Wilts, 2010.

[8] Solak, C.N. The application of diatom indices in the Upper Porsuk River, Kutahya-Turkey, Turk. J. Fish. Aquat. Sci., Vol.11: 31-36, 2011.

[9] Solak, C.N., S. Barinova, E. Acs \& H. Dayioglu. Diversity and ecology of diatoms from Felent creek (Sakarya river basin), Turkey, Turk. J. Bot., Vol.36: 191-203, 2012.

[10] Barinova, S. Algal diversity dynamics, ecological assessment, and monitoring in the river ecosystems of the eastern 
Mediterranean, Nova Science Publishers, New York, 2011.

[11] Van Dam, H., A. Mertens \& J. Sinkeldam. A coded checklist and ecological indicator values of freshwater diatoms from The Netherlands, Neth. J. Aquat. Ecol., Vol.28: 117-133, 1994.

[12] Barinova, S.S., L.A. Medvedeva \& O.V. Anissimova. Diversity of algal indicators in environmental assessment, Pilies Studio, Tel Aviv (book in Russian with a summary in English), 2006.

[13] Sarazoğlu, H. Vegetation, streams, and lakes, Ministry of Public Education, Teacher Books, 177 serial, Istanbul, 1990.

[14] Abell, R., Thieme, M.L., Revenga, C., Bryer, M., Kottelat, M. et al. Freshwater ecoregions of the World: A new map of biogeographic units for freshwater biodiversity conservation, Biosci., Vol.58, No.5: 403-414, 2008.

[15] Koç, C. The effects of water level fluctuations and some physical and chemical variables on the macrophyte density in Lake Işıkl1, Turkey, Lake Reservoir Management, Vol.24, No.2: 196-206, 2008.

[16] Bulut, C., R. Atay, K. Uysal \& E. Köse. Evaluation of surface water quality in Çivril Lake, Life Sci. Biotechnol., Vol.2, No.1: 1-8 (article in Turkish with an abstract in English), 2012.

[17] Balık, S., H.M. Sarı, R.M. Ustaoğlu \& A. İlhan. Age and growth characteristics of chub (Leuciscus cephalus L., 1758) population in Işıklı Lake, Çivril, Denizli, Turkey, EU J. Fish Aquatic Sci., Vol.21, No.3-4: 257 - 262, 2004.

[18] Blümel, C. Taxonomy and nomenclature. In: Schubert, H. \& I. Blindow (ed.): Charophytes of the Baltic Sea, pp. 261-284. Gantner Verlag, Ruggell, Liechtenstein, 2003.

[19] Schneider, S., C. Ziegler, A. Melzer. Growth towards light as an adaptation to high light conditions in Chara branches, New Phytologist, Vol.172: 83-91, 2006.

[20] Langangen, A. Charophytes of the Nordic countries, Saeculum ANS, Oslo, 2007.

[21] Blaženčić, J., B. Stevanović, Z. Blaženčić \& V. Stevanović. Red data list of Charophytes in the Balkans, Biodivers. Conserv., Vol.15: 3445-3457, 2006.

[22] Cărăus, I. Algae of Romania. A distributional checklist of actual algae. Studii si Cercetări, Biologie, Vol.7: 1-809, 2012.

[23] Caisová, L. \& M. Gąbka. Charophytes (Characeae, Charophyta) in the Czech Republic: taxonomy, autecology and distribution, Fottea, Vol.9, No.1: 1-43, 2009.

[24] Horecká, M. The significant role of Chara hispida - grown in water regime of a Gravel Pit Lake at Senec, Arch. Protistenkd., 139: 275-278, 1991.

[25] Pichler, C. Die characeenflora des Neufelder Sees (Burgenland), Verh. Zool.- Bot. Ges. Österreich, Vol.134: 33-46, 1997.

[26] Zviedre, E. Genus Chara L. in Latvia - freshwater species and their identification, Acta Biol. Univ. Daugavpils, Vol.7, No.2: 139-147, 2007.

[27] Sinkevičiene, Z. \& N. Urbaitė-Maževič. Lychnothamnus barbatus (Meyen) Leonh. - rediscovered in shalow lake
Šventininkai (Lithuania) after 50 years, Biodiv. Res. Conserv., Vol.25, No.1: 91-96, 2012.

[28] Compère, P. Charophytes, Flore pratique des Algues d'eau douce de Belgique, 4, Jardin Botanique National de Belgique, Meise, 1992.

[29] Simons, J. \& E. Nat. Past and present distribution of stoneworts (Characeae) in the Netherlands, Hydrobiologia, Vol.340: 127-135, 1996.

[30] Auderset Joye, D., E. Castella \& J.-B. Lachavanne. Occurrence of Characeae in Switzerland over the last two centuries (1800-2000), Aquatic Bot., Vol.72: 369-385, 2002.

[31] Korsch, H., U. Raabe \& K. van de Weyer. Verbreitungskarten der Characeen Deutschlands, Rostock Meeresbiol. Beitr., Vol.19: 57-108, 2008.

[32] Dąmbska, I. Flora słodkowodna Polski 13. Charophyta Ramienice. Państwowe wydawnictwo naukowe, Warszawa, 1964.

[33] Hollerbach, M.M. Sistematicheskiy spisok harovyh vodorosley, obnaruzhennyh v predelah SSSR po $1935 \mathrm{~g}$. vklyuchitelno, Tr. Bot. Inst. V.L. Komarov, USSR, Seriya II, Vol.5: 20-94 (book in Russian), 1950.

[34] Fursaev, A.D. \& N.M. Eliasch. K poznaniyu harovyh yugo-vostoka Evropeyskoy chasty SSSR, Uchenye zapiski SGU Ser. Boil., Vol.1, No.14: 91-92 (article in Russian), 1937.

[35] Krause, W. Charales (Charophyceae). In: Ettl, H., G. Gärtner, H. Heynig \& D. Mollenhauer (eds.): Süßwasserflora von Mitteleuropa, Band 18, pp. 1-202, Gustav Fischer Verlag, Jena, Stuttgart, Lubeck, Ulm, 1997.

[36] Bryant, J.A. \& N.F. Stewart. Order Charales. In: John, D.M., B.A. Whitton \& A.J. Brook (eds.): Freshwater algal flora of the British Isles: an identification guide to freshwater and terrestrial algae, pp. 593-612, Cambridge University Press, Cambridge, 2002.

[37] Hart, H.C. XIX Report on the Botany of Sinai and South Palestine, The transactions of the Royal Irish Academy, Vol.28: 373-452, P1. XV-XVII, 1885.

[38] Bent, J.Th. Southern Arabia, Smith, Elder, and Co., London, 1900.

[39] Kostin, V.A. Materialy k izucheniyu ecologii harovyh vodorosley vodoemov Ili-Balhashskogo basseyna, Bot. Materialy Gerb. Inst. Bot. KazSSR, Vol.15: 128-133 (article in Russian), 1987.

[40] Soulié-Märsche, I., A. Benkaddour, N. El Khiati, P. Gemayel \& M. Ramdani. Charophytes, indicateurs de paléobathymétrie du lac Tigalmamine (Moyen-Atlas, Maroc), Geobios, Vol.41: 435-444, 2008.

[41] Corillion, R. Les Characées du Nord de l'Afrique: éléments floristiques et distribution, Bull. Soc. Et. sci. Anjou, N.S., Vol.10: 27-34, 1978.

[42] Hustedt, F. Systematisch und Okologische Untersuchungen Uber die Diatomeenflora von Java, Bali und Sumatra. Arch. Hydrobiol. Suppl. 15: 131-177, 393-506, 638-790; 16: 1-155, 274-394, 1938-1939.

[43] Hustedt, F. Die Diatomeenflora des Flußsystems der Weser im Gebiet der Hansestadt Bremen. Abhandl. Naturw. Ver. 
Bremen, Vol.34: 181-440, 1957.

[44] Watanabe, T., K. Asai \& A. Houki. Numerical estimation to organic pollution of flowing water by using the epilithic diatom assemblage - Diatom Assemblage Index (DAIpo). Sci. Tot. Envir., Vol.55: 209-218, 1986.

[45] Sládeček, V. System of water quality from the biological point of view. Ergebnisse der Limnologie, Vol.7: 1-128, 1973.

[46] Sládeček, V. Diatoms as indicators of organic pollution. Acta Hydroch. Hydrob., Vol.14: 555-566, 1986.

[47] Lacoul, P. \& B. Freedman. Environmental influences on aquatic plants in freshwater ecosystems. Environ. Rev., Vol.14: 89-136, 2006.

[48] Vale, M. \& I.P. Holman. Understanding the hydrological functioning of a shallow lake system within a coastal karstic aquifer in Wales, UK. J. Hydrol., Vol.376: 285-294, 2009.

[49] Haas, J.N. First identification key for charophyte oospores from central Europe. Europ. J. Phycol., Vol.29, No.4: 227-235, 1994.

[50] Olsen, S. Danish Charophyta. Chorological, ecological and biological investigations. Det. Kongelige Danske Videskabernes Selskap, Biologiske Skrifter, Vol.II(1): 1-240, 1944.

[51] Haycock, B. \& G. Hinton. Monitoring stoneworts Chara spp. at Bosherston Lakes. In: Hurford, C., M. Schneider \& I. Cowx (eds.): Conservation Monitoring in Freshwater Habitats: A Practical Guide and Case Studies, pp. 277-290. Springer, Dordrecht, Heidelberg, London, New York, 2010.

[52] Rodrigo, M.A., C. Rojo, M. Бlvarez-Cobelas \& S. Cirujano. Chara hispida beds as a sink of nitrogen: Evidence from growth, nitrogen uptake and decomposition. Aquatic Bot., Vol.87: 7-14, 2007.

[53] Celewicz-Gołdyn, S., M. Klimko, N. Kuczyńska-Kippen \& B. Nagengast. Relationship between plankton assemblages and habitat characteristics of stands of Typha angustifolia and Chara hispida in Lake Wielkowiejskie. Oceanol. Hydrobiol. Stud., Vol.39, No.1: 127-135, 2010.

[54] Wium-Andersen, S., U. Anthoni, C. Christophersen \& G. Houen. Allelopathic effects on phytoplankton by substances isolated from aquatic macrophytes (Charales). Oikos, Vol.39: 187-190, 1982

[55] Kohler, A. \& S. Schneider. Macrophytes as bioindicators. Large Rivers, Vol.14, No.1-2: 17-31, 2003.

[56] Andrews, M., R. Box, S. McInroy \& J.A. Raven. Growth of Chara hispida: II. Shade adaptation. J. Ecol., Vol.72, No.3: $885-895,1984$.

[57] Mannschreck, B. Chara hispida (L.) Hartm. 1820. In: Schubert, I. \& H. Blindow (eds.): Charophytes of the Baltic Sea, pp. 107-112, Gantner Verlag, Ruggell, Liechtenstein, 2003.

[58] Blindow, I. Decline of charophytes during eutrophication: comparison with angiosperms. Freshwater Biol., Vol.28: 9-14, 1992.

[59] Melzer, A. Aquatic macrophytes as tools for lake management. Hydrobiologia, Vol.395/396: 181-190, 1999.
[60] Simons, J., M. Ohm \& R. Daalder. Restoration of Botshol (The Netherlands) by reduction of external nutrient load: Recovery of the Characean community, Hydrobiol. Bull., Vol.25, No.3: 287-294, 1992.

[61] Hilta, S., E.M. Gross, M. Hupfer, H. Morscheid, J. Mдhlmann et al. Restoration of submerged vegetation in shallow eutrophic lakes - A guideline and state of the art in Germany, Limnologica - Ecology and Management of Inland Waters, Vol.36: 155-171, 2006.

[62] Aysel, V. Check-list of the freshwater algae of Turkey, J. Black Sea/ Mediterranean Envir., Vol.11: 1-124, 2005.

[63] Romanov, R.E., Barinova S.S. The charophytes of Israel: historical and contemporary species richness, distribution, and ecology, Biodiv. Res. Conserv., Vol.25: 67-74, 2012.

[64] Yehuda, G., S.S. Barinova, T. Krugman, T. Pavlicek, Y. Nov, E. Nevo. Microscale Adaptive Response of Charophytes of the Negev Desert, Israel: Species Divergences by AFLP, Nat. Res. Conserv., Vol.1, No.3: 55-64, 2013.

[65] Löffler, H. Beitrage zur Kenntnis Der Iranischen Binnengewässer. I. Der Niriz-See und Sein Einzugsgebiet. Int. Rev. ges. Hydrobiol. Hydrogr., Vol.44, No.1-4: 227-276, 1959.

[66] [66] Soulié-Märsche, I., M. Benammi, P. Gemayel. Biogeography of living and fossil Nitellopsis (Charophyta) in relationship to new finds from Morocco, J. Biogeogr., Vol.29: 1703-1711, 2002.

[67] Dogadina, T.V., B. Darki Zarei, \& O.S. Gorbulin. Algal flora of Iran, V.N. Karazin Kharkiv national university, Kharkov, 2007.

[68] Ahmadi, A., H. Riahi, M. Sheidai \& J.C. van Raam. A study of the oospore characteristics in some Charophytes (Characeae) of Iran, Nova Hedwigia, Vol.94, No.3-4: 487-504, 2012.

[69] Ahmadi, A., H. Riahi, M. Sheidai \& J. van Raam. Some Charophytes (Characeae, Charophyta) from Central and Western of Iran including Chara kohrangiana species nova, Crypt. Algol., Vol.33, No.4: 359-390, 2012.

[70] Nahutzrishvili, I.G. (ed.). Flora sporovyh rasteniy Gruzii: Konspekt. Metsniereba, Tbilisi (book in Russian), 1986.

[71] Hussain, M.I., T.M. Khoja \& M. Guerlesquin. Chemistry, ecology and seasonal succession of Charophytes in the Al-Kharj Irrigation Canal, Saudi Arabia, Hydrobiologia, Vol.333: 129-137, 1996.

[72] Hussain, M.I. \& T.M. Khoja. Chara braunii (Charales, Charophyta) in an arid rainfed waterbody, Saudi Arabia, Aust. J. Bot., Vol.47: 427-436, 1999.

[73] Khoja, T.M. Impact of human activity on biotic communities in the Al Qatif Oasis, Saudi Arabia, Pakistan J. Biol. Sci., Vol.3, No.2: 209-214, 2000.

[74] Hussain, M.I., R. Victor \& T.M. Khoja. Charophytes of the Sultanate of Oman, Southern Arabia, Nova Hedwigia, Vol.77, No.3-4: 429-444, 2003.

[75] Demiriz, H. An annotated bibliography of Turkish flora and vegetation, The Scientific and Technical Research Council of Turkey, Ankara, 1993.

[76] Taskin, E., M. Öztürk, O. Kurt, M. \& Öztürk. The check-list of the marine algae of Turkey, Ecem Kirtasiye, Manisa, 2008. 
[77] Fritsch, K. Beitrag zur flora von Constantinopel. Bearbeitung der von J. Nemetz in den jahren 1894-1897 in den umgebungen von Constantinopel gesammelten pflanzen. I. Kryptogamen. Denkschriften d. Kais. Akad. d. Wiss. Math. Naturw., Classe LXMII: 219-250, 1900.

[78] Migula, W. Die Characeen Deutschlands, Oesterreichs und der Schweiz. Unter Berücksichtigung aller Arten Europas. L. Rabenhorst - Kryptogamenflora von Deutschland, Oesterreich und der Schweiz, 2. Aufl. Vol.5. XII (3), Kummer Verlag, Leipzig, 1897.

[79] Groves, J. \& G.R. Bullock-Webster. The British Charophyta, 2, Chareae, Ray Society, London, 1924.

[80] Saygideğer, S. The morphological, ecological and physiological properties of Chara vulgaris L. and Nitella opaca C.A. Agardh (Characeae), Ekoloji, Vol.28: 13-17 (article in Turkish with an abstract in English), 1998.

[81] Beklioğlu, M., O. İnce \& I. Tüzün. Restoration of the eutrophic Lake Eymir, Turkey, by biomanipulation after a major external nutrient control I, Hydrobiologia, Vol.489: 93-105, 2003.

[82] Taş, B. General characteristics and some environmental problems of Derbent Dam Lake (Bafra-Samsun). Ulusal Su Günleri 2005, 28-30 Eylül 2005, Trabzon, pp. 199-205 (article in Turkish with an abstract in English), 2005.

[83] Soylu, E.N., F. Maraşlioğlu \& A. Gönülol. Phytoplankton seasonality of a shallow turbid lake, Algol. Stud., Vol.123: 95-110, 2007.

[84] Groves, J. \& G.R. Bullock-Webster. The British Charophyta. I. Nitelleae, Ray Society, London, 1920.

[85] Vilhelm, J. Characeae Europae orientalis et Asiae ex herbario instituti cryptogamici horti botanici reipublicae rossicae (ante Petropolitani), Spisy vydávané Prirodovedeckov Fakultov Karlovy University (Publications de la Faculté des Sciences de l'Université Charles, Praha), Vol.80: 1-24, 1928 